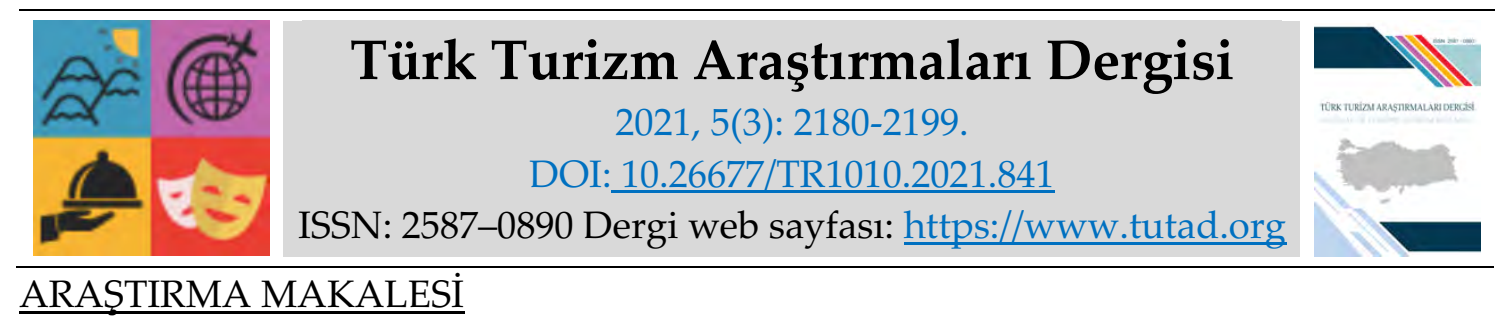

\title{
İstanbul Otellerinde İşyerinden Ayrılma Niyetini Etkileyen Faktörler: İnsan Kaynakları Yönetimi Stratejilerinin Belirlenmesi*
}

Dr. Öğr. Üyesi Burçin HATİPOĞLU, University of New South Wales, Canberra İşletme Fakültesi, Avustralya, e-posta: $\underline{\text { b.hatipoglu@unsw.edu.au }}$ ORCID: https://orcid.org/0000-0002-6048-4647

Prof. Dr. Kıvanç İNELMEN, Boğaziçi Üniversitesi, Uygulamalı Bilimler Yüksekokulu, İstanbul, e-posta: inelmenk@boun.edu.tr ORCID: https://orcid.org/0000-0001-7986-7886

Öz

Araştırmanın amacı otel kategorileri ve işgören gruplarına bağlı olarak işten ayrılma niyetinin kaynaklarını belirlemek ve elde edilen bulguların ışığında, farklı ihtiyaçlara yönelik etkin insan kaynakları (IKK) yönetimi stratejileri önermektir. Araştırma, İstanbul ilinde bulunan 38 şehir otelinin işgören (n1=707), yönetici (n2=137) ve İK departmanlarından toplanan verilerin ışığında gerçekleştirilmiştir. Bulgular otel kategorilerine ve işgören gruplarına göre işten ayrılma niyetinde anlamlı farklılıklar olduğunu göstermiştir. Bu çerçevede, özellikle eğitimli işgörenlerin gelişmeye yönelik ihtiyaçlarını karşılamak için koçluk ve mentörlük faaliyetlerinin geliştirilmesi; yöneticiler için ise işverene güveni pekiştirmek için zamanında açık ve doğru iletişimin sağlanması tavsiye edilmektedir. İşören ve yöneticilerin işyerinden ayrılma niyetinin, üç yıldızlı otellerde diğer otel kategorilerine göre daha düşük olduğu görülmüş, diğer oteller için işgörenlerin özerkliği artırıcı İK uygulamaları önerilmiştir. Öneriler yüksek performanslı insan kaynakları uygulamaları çerçevesinde değerlendirilmiştir. Araştırmanın bulguları yönetim alanında bağlamsal yaklaşımı desteklemiş ve teorik bilgi birikimine katkıda bulunmuştur.

* Araştırma Boğaziçi Üniversitesi BAP projeleri No: 6510 desteğiyle gerçekleştirilmiştir.

Anahtar Kelimeler: Yüksek Performanslı İnsan Kaynakları Uygulamaları, İşverene Güven, İşten Ayrılma Niyeti, Bağlamsal Yaklaşım, Konaklama Sektörü

Makale Gönderme Tarihi: 08.06.2021

Makale Kabul Tarihi: 03.09.2021

\section{Önerilen Atıf:}

Hatipoğlu, B. ve İnelmen, K. (2021). İstanbul Otellerinde İşyerinden Ayrılma Niyetini Etkileyen Faktörler: İnsan Kaynakları Yönetimi Stratejilerinin Belirlenmesi, Türk Turizm Araştırmaları Dergisi, 5(3): 2180-2199.

(C) 2021 Türk Turizm Araştırmaları Dergisi. 


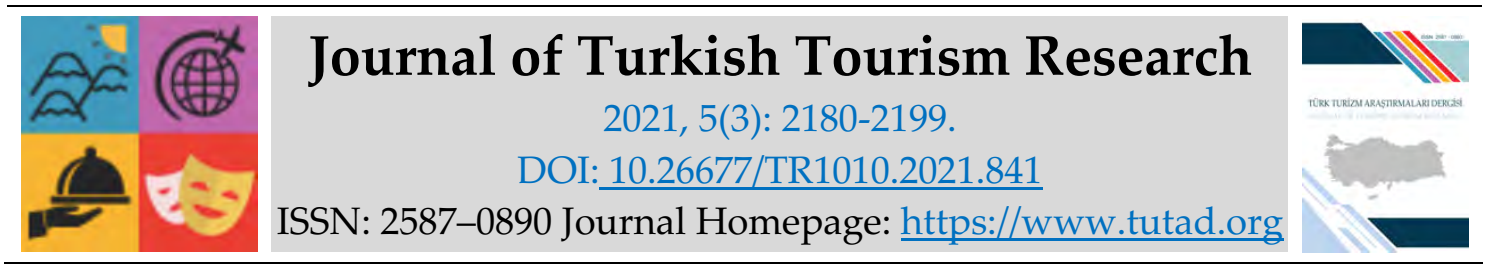

\title{
$\underline{\text { RESEARCH PAPER }}$
}

\section{Factors Affecting the Intention to Leave in İstanbul Hotels: Determining the Human Resource Management Strategies}

Assistant Prof. Dr. Burcin HATIPOGLU, University of New South Wales, Canberra School of Business, Australia, e-mail: b.hatipoglu@unsw.edu.au

ORCID: https://orcid.org/0000-0002-6048-4647

Prof. Dr. Kıvanç İNELMEN, Boğaziçi University, School of Applied Sciences, İstanbul, e-mail: inelmenk@boun.edu.tr

ORCID: https://orcid.org/0000-0001-7986-7886

\begin{abstract}
The study aims to determine the sources of intention to quit using hotel categories and employee groups and propose effective human resource management (HRM) strategies. The data was collected from the employees (n1=707), managers ( $2=137)$, and HRM departments of 38 city hotels in Istanbul. The results showed significant differences in the intention to quit according to hotel categories and employee groups. Given that educated employees were more likely to quit, coaching and mentoring activities to meet the employees' growth needs are recommended. As trust in the employer was found to be essential for managers, timely and accurate communication of strategies was suggested. Intention to quit among managers and employees of the 3-star hotels was lower compared with their counterparts. It was concluded that HRM strategies to increase the autonomy of staff could be beneficial. The study findings contribute to the high-performance human resource practices and contextualist approach in management theory.
\end{abstract}

Keywords: High-Performance Human Resource Practices, Trust in The Employer, Intention to Leave, Contextualist Approach, Hospitality.

Received: 08.06.2021

Accepted: 03.09.2021

\section{Suggested Citation:}

Hatipoğlu, B. and İnelmen, K. (2021). Factors Affecting the Intention to Leave in Istanbul Hotels: Determining the Human Resource Management Strategies, Journal of Turkish Tourism Research, 5(3): 2180-2199.

(C) 2021 Türk Turizm Araştırmaları Dergisi. 


\section{Gíriş}

Günümüzde kullanılan yönetim modelleri geçmişe kıyasla daha fazla insan odaklıdır ve insan kaynağının etkin kullanımının işletme başarısını olumlu etkileyeceği varsayılarak geliştirilmiştir. Dolayısıyla modern işletmelerde insan kaynakları (IK) yönetimi, işgörenlerin kaliteli üretim ve hizmete olan bağlılıklarını geliştirmeyi ve onların sürekli iyileştirme süreçlerine katkıda bulunabilecekleri ve yaratıcı ve yenilikçi olabilecekleri ortamlar yaratmayı hedefler (Hoque, 2000). Gerçekleştirilen araştırmaların bulguları, doğru İK politika ve uygulamalarının örgütlerde birçok olumlu etkisi olduğunu göstermiştir. Çalışmalar yüksek performanslı insan kaynakları yönetiminin işgören verimliliğini ve işe adanmışlığ (Gürlek 2020; He, Morrison, ve Zhang, 2021; Karadas ve Karatepe 2019) ve işgören devir oranını iyileştirdiğini (Boxall ve Macky, 2009) göstermiştir. Zaman içinde İK, birçok ülkede olduğu gibi, Türkiye' deki işletmeler tarafından da rekabetçiliği sağlamanın ana unsuru olarak kabul edilmiştir (Aycan, 2006).

İşletmelerde dikkatle yönetilmesi gereken süreçlerden bir tanesi işgörenlerin işten ayrılmalarıdır. İşten ayrılan her işgören tecrübe yoluyla kazandığı ve örgüt için değerli bilgi ve tecrübeleri alıp beraberinde götürmektedir. Dolayısıyla, yüksek işgören devir hızının işletmelerin başarısı üzerinde doğrudan ve dolaylı olumsuz etkileri vardır ve bu nedenle işletmeler için iyi yönetilmesi gereken bir göstergedir. Her sektör için kabul edilebilir işgören devir hızı vardır, bazı sektörlerin diğerlerine göre çok daha yüksektir (Deery ve Jago, 2009). İşgörenlerce algılanan iş güvencesizliğinin, işten ayrılma niyetinin boyutu üzerindeki etkisi oldukça önemli bir düzeydedir (Keser ve Dursun, 2017). Konaklama sektöründe işgörenlerin demografik özelliklerini, turizmin mevsimsellik özelliği, çalışma tiplerini ve uzun çalışma saatlerini dikkate alındığında işgören devir hızının diğer sektörlere göre neden daha yüksek olduğunu daha iyi anlaşılmaktadır (Deery ve Jago, 2009; Erdoğan Morçin ve Coşkun, 2020). Konaklama sektöründe İK yöneticilerinin işgören bağlllığını artırmak ve işten ayrılmaları azaltmak için düzenli ve planlı İK yönetim araçlarını etkin uygulamaları gerekir. Konaklama sektöründe işgörenlerin etkin yönetimi misafir memnuniyetine ve dolayısıyla işletme başarısına da yansıyacaktır (Kim, 2009; Chand, 2010; Karatepe, 2013; Kirant Yozcu, 2020).

İşgücünün homojen olduğu varsayımı ile hareket edilmesi yanıltıcı olabilecektir. Geçmişe göre işyerlerinde daha fazla kadın işgören, ileri yaşta işgören ve yabancı uyruklu işgören bulunmaktadır. Dolayısıyla bu farklılıkların işgücünün iş tutum ve davranışlarına yansıyacağı varsayılabilir. Örneğin kamu sektöründe gerçekleştirilen bir araştırmada kadın işgörenler mesleki ayrıma tabii tutuldukların ve bu nedenle uygulanan politikalar doğrultusunda yükselemediklerini belirtmişlerdir (Bingöl vd., 2011). Tercih edilebilecek İK perspektifinin durumsal farklılıklar göz önüne alınarak geliştirilmesi yerinde olabilecektir (Koçel, 1989).

Çalışmanın amaçları sırasıyla; otel kategorileri ve işgören gruplarına bağlı olarak işten ayrılma niyetinin belli başlı kaynaklarını belirlemek ve elde edilen bulguların ışığında, farklı ihtiyaçlara yönelik etkin IKK stratejileri belirlenmesidir. Yazında ortaya konulduğu üzere, yüksek performanslı insan kaynakları yönetim uygulamalarının çalışan tutum ve davranışlarına olası etkisi nedeniyle çalışmaya dahil edilmişlerdir. Ayrıca 1990'lı yıllardan beri yapılan çalışmalarda iş yerlerindeki güven yapısının, kişilerarası ilişkilerin temeli olduğu kadar, örgütlerin rekabet avantajı elde edebilecek kaynaklarını oluşturmasında da etkili olduğu öne sürülmektedir (Tan ve Lim, 2009). Örgütlerin rekabet üstünlügü kazanabilmesi ise ancak çalışanlarının örgüte olan bağlılıklarıyla mümkün olacaktır. Çalışanların işverenlerine duydukları güven, bu bağlılığın oluşmasında ve işyerinden ayrılma niyetinin azalmasındaki önemli unsurlardan birisidir. Bu yüzden örgütsel teori ve araştırmalarda önemli rol üstlenen işverene güven hem çalışanlar hem 
de örgütler için önem taşımaktadır. Ancak tek tip bir çalışan grubundan, özellikle de konaklama sektörü örgütlerindeki ihtiyaçların çeşitliliği düşünüldüğünde, bahsetmek de hatalı olabilecektir. Dolayısıyla, konaklama sektöründe daha önce de işgören ve yönetici grupları ayrıştırılarak İK uygulamaları araştırılmış olması şaşırtıcı değildir (Lu, Lu, Gursoy ve Neale, 2016; DomínguezFalcón, Martín-Santana ve De Saá-Pérez, 2016). Ayrıca konaklama sektöründe önemli bir yeri olan otel kategorileri de işyerinden ayrılma niyeti bakımından farklılık oluşturabileceği doğrultusundaki bulguların da 1şığında (Hatipoğlu, Alvarez, İnelmen ve Ünalan, 2013) araştırmaya dâhil edilmiştir. Özetle, bu çalışmada amaçlanan, farklı işgören grupları ve otel kategorilerine göre farklı İ stratejilerinin gerekip, gerekmediği konusunda kapsamlı bir değerlendirme ortaya koyabilmektir.

\section{KAVRAMSAL ÇERÇEVE}

Bir yönetim işlevi olarak ortaya çıkışından bugüne kadar, İK zaman içinde örgüt çıktılarına olan katkısını göstermiş ve örgüt içinde stratejik önemini artırmıştır (Macky ve Boxall, 2007). Örgütler stratejileri ve yönetim prensipleri doğrultusunda kendilerine uygun İK politikaları ve uygulamaları belirlemektedirler. İK yönetimi "herhangi bir örgütsel ve çevresel ortamda insan kaynaklarının örgüte, bireye ve çevreye yararlı olacak şekilde, yasalarda uyularak, etkin yönetilmesini sağlayan işlev ve çalışmaların tümü" olarak tanımlanabilir (Sadullah, 2015: 3). Büyük işletmeler sıklıkla yöneticileri için bir İK sistemi, üretim ve hizmet işgörenleri için ise ayrı bir İK sistemi benimser ve uygular (Boxall ve Purcell, 2007). Bu sistemler aralarında benzerlik gösterse de işe alım stratejileri, eğitim sistemleri ve performans ölçütleri birbirinden önemli derecede farklıdır.

İK uygulamaları yönetsel başarıyı artırmak ve daha yüksek performans yakalamak adına işgörenlerin teknik bilgilerini ve yetkinliklerini artırabilir ve olumlu örgütsel davranışlar sergilemelerini sağlayabilir. Yüksek performanslı İK uygulamaları, işgörenlerin yetkinliklerinin artırılması, yetkilendirilmeleri ve ödüllendirilmeleri yolu ile güçlendirilmelerine dayanır (Macky ve Boxall, 2007). Yetkilendirilen işgörenler işlerine karşı daha motive olacaklar, yetkinlikleri artığ 1 için daha verimli olacaklar ve dolayısıyla işletme başarısına katkıda bulunacaklardır. Huselid (1995) insan kaynakları yönetiminde yüksek performans göstergesi olarak 13 adet uygulama belirlemiştir. Araştırmacı, 968 Amerikan işletmesinde gerçekleştirdiği çalışmada, yüksek performanslı İK uygulamalarının işgören devir hızını düşürdüğünü, verimliliği artırdığını ve dolayısıyla işletme finansal başarı göstergelerine katkıda bulunduğunu saptamıştır. Ayrıca bu alanda gerçekleştirilen çalışmalar yüksek performanslı İK uygulamalarının iş tatmini, işverene güven ve örgütsel bağlllık gibi işgörenlerin tutum ve davranışlarına da olumlu etkileri olduğunu göstermiştir (Macky ve Boxall 2007; Karadas ve Karatepe 2019). Adil uygulanan terfi sistemi, karar mekanizmalarına katılım ve performans yönetimi beraber kullanıldığında, en etkin sonuçlar elde edilmektedir.

Konaklama sektöründe fiziksel özellikler (otelin konumu, binası, oda özelikleri, vb.) önemlidir ancak bununla birlikte işgörenlerin yetkinlikleri, tutum ve davranışları da misafir memnuniyetini etkilemektedir (Alvarez ve Hatipoğlu, 2014). Yüksek performanslı İK uygulamaları içinden farklı kombinasyonlar seçilerek otel işgörenleri, misafir memnuniyeti ve işletme başarısı üzerindeki etkileri birçok ülkede araştırılmıştır (Murphy, Torres, Ingram ve Hutchinson, 2018). Amerika'da bulunan otel ve restoran işletmelerinin 12 yüksek performanslı İK uygulamasını inceleyen bir araştırma, işgörenlerin işten ayrılma niyetini azaltmakta katılımcı uygulamaların (kalite çemberleri veya iş-yaşam dengesi programlarının), performansa dayalı ücretlendirmenin ve seçici işe alımın etkili olduğunu göstermiştir (Cho, Woods, Jang ve Erdem, 2006). Karatepe (2013) 
Romanya' da 110 otel işgörene ve onların yöneticileriyle yaptığı araştırmada yüksek performanslı İK uygulamaları içinden eğitim, güçlendirme ve ödüllendirmenin etkilerini araştırmıştır. Bu uygulamalar işgörenlerin işlerine karşı tutkunluğunu artırmakta, işgören performansını iyileştirmekte ve otel misafirlerine de olumlu olarak yansımaktadır.

İspanya'da yapılan bir araştırmada da yüksek bağlılık yaratacak İK prensiplerini uygulayan otellerde şeflerin ve yöneticilerin iş tatmininin ve bağl1lıkların artığı gözlenmiştir (DomínguezFalcón, Martín-Santana ve De Saá-Pérez, 2016). Şeflerin bağlllı̆̆ ve memnuniyeti ise doğrudan misafir memnuniyetini olumlu yönde etkilemektedir. İran'da dört ve beş yıldızlı otellerde gerçekleştirilen başka bir çalışmada (Safavi ve Karatepe, 2018) ise seçilen 8 uygulamanın işgörenlerin yetkinliklerini artırdığı ve dolayısıyla kariyer uyum sağlayabilirliği üzerinde olumlu etkileri olduğu görülmüştür. Seçici işe alım, iş-yaşam dengesi ve kariyer yönetimi gibi İK uygulamaları özellikle misafir ile doğrudan iletişim içinde bulunan işgörenlerin işten beklentilerinin karşılanmasına neden olmaktadır. Aynı şekilde seçici işe alım, eğitim ve ödüllendirme de işgörenlerin işlerinde yaratıcılıklarının artmasına ve olumlu misafir ilişkilerine neden olmaktadır. Belirtilen çalışmaların ışığında, iyi işleyen İK politika ve uygulamalarının rekabet avantajı elde etmeye çalışan İstanbul otelleri için de önemli olacağı açıktır.

İşverene Güven Bir toplumdaki kişiler ve kurumlar arasında bulunan güven (sosyal sermaye) o ülkenin "ekonomik, sosyal ve siyasal alandaki" başarısı ile yakından ilgilidir (Karagül ve Dündar, 2006: 62). Bu nedenle sosyal sermayeyi iyileştirecek yatırımlar ülkenin gelişmişliğini etkileyecektir. Aynı şekilde işletmelerde de yönetim tarafından geliştirilmek istenen olumlu örgütsel davranışlar içinde diğerleri ile işverene güvenin ön planda olduğu söylenebilir (Hatipoglu ve Inelmen, 2018). İşverene güven olgusu işletmenin başarısını doğrudan veya dolaylı olarak etkileyen işgörenlerin iş tatmini, işe bağlılık ve işten ayrılma niyeti ile yakından ilişkilidir ve bu nedenle çok önemsenmektedir. İşverene güvenin geliştirilmesi için en etkin yönetimsel aracın istikrarlı İK uygulamaları olduğu düşünülmektedir (Searle ve Dietz, 2012). Esasen, İK birimi işverene güveni geliştirmeyi işe alımdan başlayarak tüm İK uygulamalarının içine dâhil edebilir ve bu şekilde olumlu birçok sonuç yaratabilir.

Duygusal Bağlılık Örgütsel bağlllık kavramı, ilk olarak ortaya atıldığı dönemlerden itibaren çoğunlukla işgörenin işyerine duygusal bağlılığı ile yakından ilişkili olarak tanımlana gelmiştir (Wasti, 2000). Daha sonra yapılan kavramsallaştırma ve modellere 'devam bağlılığı' ve 'normatif' ya da 'minnet bağlılığı' da eklenmiş olmakla birlikte (Meyer ve Allen, 1991), işgörenlerin duygusal bağlllığı önemini hiç kaybetmemiştir. Her üç tip bağlllı̆̆ında örgütten ayrılma niyetini azalttığı, fakat bunların farklı etmenler sonucunda geliştikleri sonucuna varılmıştır. Bu bağlamda, duygusal bağllığın olumlu iş deneyimleri sonucunda ortaya çıktığı ve iş verimine belirgin bir katkısının olduğunu söylemek yanıltıcı olmayacaktır (Wasti, 2000). Bazı araştırmacılar (Kazlauskaite vd., 2006), duygusal bağlılık boyutunu, konaklama işletmelerinde örgütsel bağlılığın ölçümü için yeterli bulmaktadır. Örneğin, geniş çaplı bir çalışmasında Whitener (2001), İK uygulamalarının, işgörenlerin örgütsel destek ile ilgili algılarının, örgüte duygusal bağlllık ve yönetime güveni önemli ölçüde etkilediği sonucuna ulaşmıştır.

Dağıtım Adaleti Dağıtım adaleti, ya da örgütün ödüllendirme sisteminin işle ilgili davranışların sergilenmesinin sonucunda örgütsel adalet algılarının ne ölçüde etkilediğiyle ilgilidir (Karriker ve Williams, 2009). Ödüllerin, eşit olmayan ya da hakkaniyete dayanmayan bir çerçevede dağıtılması, ya da bu yönde algıların oluşması işgörenler için sorun oluşturmakta, adalet algısı zedelenen işgörenlerin işyerlerinden ayrılma niyetini arttırmaktadır. Yapılan çalışmalarda dağıtım adaletinin, üste güven ile kişi-örgüt uyumu arasındaki ilişkide düzenleyici etkiye sahip olduğunu da göstermiştir (Turunç ve Çelik, 2012). 
Lider-Üye Etkileşimi Lider-Üye Etkileşimi teorisine göre liderler ve kendilerine bağlı işgörenler arasında farklı nitelikli ilişkiler gelişebilmektedir. Bu teoriye göre liderlerin çalışma grubu içindeki tüm grup üyeleriyle, benzer bir liderlik tarzı çerçevesinde etkileşimde bulunmadığını ileri sürmektedir (Graen ve Uhl-Bien, 1995; Kim ve Koo 2017). Buna göre bir lidere bağlllık gösteren işgörenler, bu ilişki için yüksek düzeyde çaba gösterme ve üstlerine kişisel bağlllık duyma eğiliminde olurlar. Buna bağlı olarak, ilişkilerin niteliği bireysel ve örgütsel sonuçları etkilemektedir. Örnek olarak bu tür işgörenlerin işyerlerinden ayrılma niyetleri de azalma göstermektedir (Şahin, 2011) ve yaratıcılıkları artmaktadır (He vd., 2021). Liderler, işgörenlerine daha fazla sosyal destek vererek, örgütsel kaynakları kullandırarak ve ödüllendirerek karşılık verme eğilimindedirler.

\section{Konaklama Sektöründe İK}

Konaklama sektörü yapısı itibari ile kendi içinde etkin İK uygulamalarını zorlayan özellikleri barındırmaktadır. Bu sorunlar dağınık coğrafi dağılım, düzensiz talep, yüksek işgören devir hızı, yarı zamanlı ve kısa dönemli işgörenler, düşük ücretler, kalifiye işgören eksikliği ve düşük işgören yetkinlik seviyeleri olarak özetlenebilir (Baum, 2007). Bunlara ilaveten sektör maliyet kontrolüne çok önem vermesi ve kontrolcü yönetim sistemleri ile de beraber anılmaktadır (Hoque, 2000). Sektörde kullanılan IKK uygulamalarını diğer sektörlerle karşılaştırıldığında, göreceli olarak daha az gelişmiş olduğunu görülür ve bu nedenle otellerin İK departmanları da sıklıkla eleştirilir (Cho, Woods, Jang ve Erdem, 2006). Otellerde İK departmanlarının işgören bağlılığı, memnuniyeti ve motivasyonu gibi iş tutum ve davranışları geliştirmekte de başarısız olduğunu söylemek mümkündür (Kusluvan, Kusluvan, Ilhan ve Buyruk, 2010). Özetle sektörün genelde insan yönetimindeki başarısı göreceli olarak düşüktür ve çok az otel işletmesi insanı stratejik olarak yönetmektedir.

Sektörün rekabetçiliği yakalamasında kalitenin öneminin çok çeşitli çalışmalar aracılığıyla vurgulanmasına rağmen bunun yansımasının İK uygulamalarında görülmeyişi dikkat çekicidir. Turizm ve İK alanında çok uzun senelerden beri çalışan Baum (2007) gelişmeye yönelik beklentisini "Turizmde İnsan Kaynakları: Halen Değişim Bekliyoruz" başlı̆̆ ile belirtmiştir. Aynı eserde araştırmacı, sektör çalışanların beklentilerini de özetlemiştir. Gelişmekte olan ülkelerde çalışanlar sektöre iş olanakları yarattığı için daha olumlu bakmaktadırlar. Ancak gelişmiş ülkelerde gençler kariyer imkânı sunmadığı için sektörü geçici görmekte ve seçmemektedirler. Konaklama sektörü geçmişte olduğu gibi geri kalmış İK süreçleri ile bilinse de çokuluslu, büyük ve zincir oteller zaman içinde İK süreçlerini diğerlerine göre geliştirmişler (Baum, 2007; Kusluvan, Kusluvan, Ilhan ve Buyruk, 2010) ve kontrolcü yönetimden daha yenilikçi ve katılımcı uygulamalara geçmişlerdir. Çok uluslu ve zincir otellerde hizmetin standartlaşması esas olduğundan verimlilik, üretkenlik ve karlılık üzerine daha fazla baskı vardır (Nankervis ve Debrah, 1995). Bu nedenle İK uygulamaları içinde seçici işe alım, kariyer geliştirmeye yönelik eğitim ve geliştirme programları ve performansa dayalı ücret politikaları gibi daha yenilikçi uygulamalar kullanılmaktadır.

Türkiye' de konaklama sektörü, uluslararasılaşma anlamında önde gelen sektörlerden biridir. İK uygulamalarının bir işletmede küresel anlamda standartlaştırılması tutarlılığı temin eder ve ayrıca farklı coğrafyalara dağılmış işgörenlerin aynı prensiplerle ve hedeflerle çalışmalarını sağladığı iddia edilmiştir (Dowling, Festing ve Engle, 2013). Ayrıca standartlaştırma yaklaşımı yöneticiler arasında eşitlik algısına katkıda bulunur ve operasyonel verimlilik elde edilir. Uygulamada standartlaştırma yaklaşımını evrenselci (universalistic) İK yaklaşımıyla benzer kabul edilmektedir. Evrenselci İK yaklaşımı diğerlerinden daha iyi olan bir takım İK 
uygulamaları olduğunu ve her örgütün başarıya ulaşmak için bunları uygulamaları gerektiğini savunmuştur (Harris, Brewster ve Sparrow, 2003). Evrenselci yaklaşımın öngördüğü şekilde belirli İK prensipleri her birimde veya ülkede uygulandığında ise standartlaşma sağlanmış olunur.

$\mathrm{Bu}$ yaklaşımdan farklı olarak bazı çokuluslu ve büyük kuruluşlar yerele duyarlı olmanın faydalarını keşfetmişler ve İK stratejilerini bu şekilde adapte etmişlerdir. Bu yaklaşım anlayışının arkasında bir ülkede veya bir kurumda başarılı olmuş bir uygulamanın diğer bir ülkede veya kurumda da mutlaka başarı getirmeyeceği anlayışı bulunmaktadır. Dolayısıyla bu yaklaşımı benimseyen kurumlar yerel kültürel değerlere, geleneklere, kanunlara ve diğer kurumsal oluşumlara saygı duyarak IKK prensiplerini geliştirir ve uygularlar (Dowling, Festing ve Engle, 2013). Uygulamada bu yaklaşımı da bağlamsal yaklaşım (contextualist) ile benzer kabul edilir. Bağlamsal yaklaşım İK açısından işletme içinde ve dışında farklıkları sorgular (Harris, Brewster ve Sparrow, 2003). Bağlamsal yaklaşım için farklılıkları açıklamak önceliklidir ve evrenselci yaklaşımdan farklı olarak işletme performansı ikincil olarak gelir.

Yukarıda bahsedilen yaklaşımda işletme içinde yöneticilerin ve işgörenlerin aynı konu ile ilgili farklı görüşleri ve yaklaşımları olabilir ve bunları anlamak ve gerekli uyarlamaların yapılması önerilmektedir. İki yaklaşımın da işletmeler açısından artıları ve eksileri bulunmaktadır. Büyük ve çokuluslu kurumlar için İK uygulamalarını standartlaştırmak veya yerelleştirmek önemli bir karardır ve dengesi işletmenin başarısını etkileyecektir. İşletmenin stratejileri ve yapısı, kültürü ve büyüklüğü gibi unsurlar bu kararlarda etkili olacaktır (Dowling, Festing ve Engle, 2013). Bu çalışmada, önceki araştırmaların ortaya çıkardığı belli başı işgören tutumlarının işyerinden ayrılma niyetine etkilerinin yanı sıra, evrenselci ve bağlamsalcı yaklaşımların İK yönetimi bakımından bir karşılaştırması da gerçekleştirilmiştir. Gerçekleştirilen çalışmaları toparlamak gerekirse İK'nın bir yönetim işlevi olarak işgören, birim ve işletme sonuçlarına katkısı olduğu görülmüştür. İşletmeler için birçok önemli iş tutumu arasında işverene güven, duygusal bağlllık, dağıtım adaleti ve lider-üye etkileşiminin kişi-örgüt uyumu için önemli olduğu ve işgörenlerin verimliğini yorumlamak için anlamlı oldukları anlaşılmıştır. Konaklama sektöründe iş tutumlarının geliştirilmesi müşteri memnuniyetini iyileştirmek için önemi vurgulanmasına rağmen, sektör stratejik İK uygulamaları geliştirememiştir.

\section{ARAŞTIRMANIN YÖNTEMI}

\section{Örneklem}

Araştırma ekibi örneklem otellerin belirlenmesinde, İstanbul'daki şehir otellerini mümkün olan en kapsamlı biçimde temsil etme hedefiyle yola çıkmıştır. Araştırmanın kapsamını geniş tutabilmek amacıyla İstanbul genelindeki toplam yatak sayısının \%80'nine yakını oluşturan otellerin üyesi olduğu Türkiye Otelciler Birliği (TÜROB) ile çalışılmıştır. TÜROB'un üye listesi Istanbul şehir otellerini inceleyen araştırmanın evreni olarak seçilmiştir. Bu listeyi takiben yapılan inceleme sonucunda, söz konusu listeyi oluşturan otellerin \%18,6'nın 5 yıldızlı, $\% 35,6$ 'sının 4 yıldızlı, \%20,6'sının 3 yıldızlı ve \%25,1'nin butik ve özel kategori oteller oldukları görülmüştür.

Araştırmanın için veri toplamak üzere seçilen otellerin, her bir kategoriyi oransal olarak temsil edecek şekilde tabakalı ve rastlantısal örnekleme yolu ile belirlenmesine karar verilmiştir. Yürütülen süreç sonucunda araştırma ekibi ilk listeyi rastlantısal olarak hazırlamıştır. Listeye dahil olan oteller TUROB ekibi tarafından çalışmaya davet edilmiştir. Bu listeye dâhil edildikleri 
halde, çalışmaya katılmayı çeşitli nedenlerle kabul etmeyen her bir otelin yerine, yine aynı kategoriden bir otelin rastlantısal olarak belirlenmesi yoluyla devam edilmiş ve bu araştırmada kullanılacak verileri sağlayan toplam 38 otelde veri toplanmıştır. Çalışma boyunca otellerin IK departmanları ile koordineli bir süreç yürütülmüştür. Araştırmaya katılan otellerin 7'si 5 yıldızlı, 17'si 4 yıldızlı, 7'si 3 yıldızlı ve 7'si butik ve özel kategori otellerdir.

\section{Verilerin Toplanması}

Araştırmayı işgören katılımını artırmak için birkaç teknik bir arada uygulanmıştır. Öncelikle otel yönetimleri ile TÜROB aracılığı ile iş birliğine gidilmiştir. İkinci olarak gizlilik konusunda katılımcılara güvence verilmiştir. Araştırmaya katılan otellere, çalışmada verileri toplamak için hazırlanan iki ayrı anket, görevlendirilen anketörler tarafından yönetici ve işgörenlere ulaştırılmış ve bir hafta sonra her biri kapalı zarf içinde geri toplanmıştır. Ayrıca, araştırma için gerekli olan ek veriler bir diğer anket ve bilgi formu yolu ile İK birimlerinden elde edilmiştir. İK otellerinden toplanan anketler göre araştırmadan yer alan otellerde toplam tam zamanlı çalışan sayısı 3305'tir. Anketlerin ön incelmesinde, 707'si işgören ve 137'si yönetici olmak üzere, toplamda 844 işgörene (toplam evrenin \%25,5'i) ve bu anketlerin elde edildiği 38 otelin İK yöneticisine de ulaşılmış olduğu görülmüştür.

\section{Kullanılan Ölçekler}

İşgören ve yöneticilere uygulanan anket formunda çeşitli ölçeklerden yararlanılmıştır. Bu ölçeklerin her biri farklı çalışmalarda daha önce kullanılmıştır. Üç sorudan oluşan işyerinden ayrılma niyeti (ör. Sık sık şu anki işyerimden ayrılmayı düşünüyorum.) ile Meyer ve Allen'in (1991) örgüt bağl1lığı modelinin üç boyutundan en belirleyicisi olarak görülen (Ozturk, Hancer ve Im, 2014) duygusal bağlılık ölçeği, altı sorudan oluşmaktadır ve (ör. Bu işletmeye duygusal anlamda bir bağlllık hissetmiyorum) Zeytinoglu ve diğerlerinin (2012) kullandığ 1 şekli ile çalışmaya dâhil edilmiştir. Ayrıca Robinson ve Rousseau'nun (1994) İşverene Güven Ölçeği (ör. Yöneticim, sorunlarımı ve ihtiyaçlarımı yeterince iyi anlar), Tekleab ve Taylor'un (2003) Liderüye Etkileşimi ve Colquitt'in (2001) geliştirdiği şekli ile örgütsel adaletin boyutlarından dağıtım adaleti ölçeği kullanılmıştır. Bahsi geçen bu ölçeklerde, ifadelerin yanıt kategorileri beşli Likert derecelemesine göre, 1 = Kesinlikle katılmıyorum .... 5 = Kesinlikle katılıyorum şeklinde olmak üzere, katılımclar tarafından değerlendirilmiştir. Kontrol değişkenleri olarak örneklemde yer alan otel işgörenlerinin cinsiyet, yaş ve eğitimleri de analize dâhil edilmiştir.

Otellerin IKK departmanlarından toplanan anketlerde ise toplam 62 soru olmak üzere; İK departmanının yapısı ile ilgili 11 soru, işgörenler ile ilgili 6 soru ve demografik bilgiler için 8 soru sorulmuştur. Yüksek performanslı İK yönetim politikalarına uygun olarak 37 soru sorulmuştur. Yüksek performanslı İK yönetim politikaları ile ilgili sorular için Huselid (1995) ve Cho ve diğerleri (2006) çalışmaları örnek alınarak alınmıştır (Tablo 1). Bu sorular kapsamında otelde yönetim ve işgörenler arasındaki iletişim, eğitim faaliyetlerinin yoğunluğu, karar verme süreçlerine katılım, kâr payı dağıtımının planlanıp, planlanmadığı ve performans yönetimi sistemine dair uygulamaları ile ilgili detaylı bilgiler sorulmuştur. 
Tablo 1. Araştırmada Kullanımı Sorgulanan İnsan Kaynakları Uygulamalarına Örnekler

\begin{tabular}{ll}
\hline İK Uygulaması & Sorular \\
\hline İletişim & $\begin{array}{l}\text { Otelinizin plan ve hedefleri ile ilgili bilgiler işgörenlere } \\
\text { yapılandırılmış yollardan (toplantı, dergi, Intranet, e-mail.) ne } \\
\text { kadarına iletiliyor? }\end{array}$ \\
\hline Eğitim & $\begin{array}{l}\text { Otelinizde en son 12 ay içerisinde işgören başına ortalama eğitim } \\
\text { saati ne kadar? }\end{array}$ \\
\hline $\begin{array}{l}\text { Karar verme } \\
\text { süreçlerine katılım }\end{array}$ & $\begin{array}{l}\text { Kalite çemberleri ve/veya işgörenin karar verme sürecine katılımı } \\
\text { tipi uygulamalarda İş görenlerinizin ne kadarı yer alıyor? }\end{array}$ \\
\hline Kar dağıtım planları & $\begin{array}{l}\text { İşörenlerin ne kadarı kar dağıtım planlarına ortak? (yıl sonu kar } \\
\text { paylaşımı, hisse paylaşımı) }\end{array}$ \\
\hline Performans Yönetim & $\begin{array}{l}\text { Oteliniz işgörenlerinin ne kadarı için performans değerlendirmesi } \\
\text { gerçekleştiriliyor? }\end{array}$ \\
\hline
\end{tabular}

\section{BULGULAR}

Araştırmaya katılan işgörenlerin demografik özelliklerine göre dağılımları incelendiğinde bu gruptaki işgörenlerin büyük bir bölümü erkektir $(\% 67,8)$. Kadın işgören oranı $(\% 31,8)$ Türkiye' de kadının istihdam oranının $(\% 27,5)$ üzerindedir (TUIK, 2021). Genel olarak, bu otellerde işgörenlerin eğitim düzeylerinin yüksek olduğunu söylemek mümkündür, çünkü neredeyse dörtte üçünden fazlası (\%42,4) üniversite (ön lisans, lisans veya yüksek lisans) ve lise mezunudur $(\% 34,2)$. Beklendiği üzere yaş ortalaması işgörenler için daha düşükken $(\% 31,4)$, yöneticiler için daha yüksektir $(37,3)$. Benzer şekilde işgörenlerin sektörde ortalama çalışma süreleri $(7,7$ yıl), yöneticilere göre daha düşüktür (15,2 yıl).

Katılımcılar için aynı işyerinde çalışma oranlarına bakıldığında ise sektörde yaygın olan yüksek devir hızına paralel olarak işgörenlerin ortalama kıdem yıllarının düşük kaldığı söylenebilir. Araştırmaya katılan otellerde işgörenlerin aynı işyerinde kalma süresi ortalama 3,6 yıl, yöneticilerin ise ortalama 7,1 yıldır. Anketi cevaplayanların çalıştıkları bölümlerin yarısından fazlası misafir ile doğrudan iletişimi olan pozisyonlardan oluşmaktadır. Katılımcıların bölümleri sırasıyla ön büro (\%22,6), yiyecek ve içecek (\%17), kat hizmetleri $(\% 14,5)$, mutfak $(\% 9,7)$, satış ve pazarlama $(\% 5)$ ve diğer bölümler oluşturmuştur.

İşörenlerin tümünün, işyerinden ayrılma niyeti ile işyerine güven, duygusal bağlılık ve dağıtım adaleti değişkenlerimizin arasında doğrusal ilişkiler olup olmadığını, bunların yön ve şiddetinin ne kadar olduğunu belirlemek amacıyla ile korelasyon analizi yapılarak, sonuçlar Tablo 2. de verilmiştir. Sonuçlar, araştırmaya dahil edilen değişkenlerimizin, beklendiği üzere işyerinden ayrılma niyeti ile olan ilişkilerin negatif yönlü ve orta derecede şiddetli olduğunu teyit eder niteliktedir. Bu analizlerin neticesinde, verilerin çoklu regresyon analizinin yordanmasının uygun olacağ1 görülmüştür. 
Tablo 2. Açıklayıcı İstatistikler ve Araştırma Değişkenleri Arasındaki Korelasyonlar ( $\mathrm{N}=844)$

\begin{tabular}{|c|c|c|c|c|c|}
\hline & Ortalama $\quad \mathrm{v}$ & & 2 & 3 & \\
\hline & Standart Sapma & & & & \\
\hline 1.İşyerinden Ayrılma Niyeti & $2,33$ (s.s. $=1,05)$ & $(0,87)$ & & & \\
\hline 2.İşverene Güven & $3,74$ (s.s. $=0,73)$ & $-0,526^{*}$ & $(0,80)$ & & \\
\hline 3.Duygusal Bağlılık & $4,38$ (s.s. $=0,94)$ & $-0,560^{*}$ & $0,638^{*}$ & $(0,74)$ & \\
\hline 4.Dağıtım Adaleti & $3,58$ (s.s. $=0,94)$ & $-0,346^{*}$ & $0,431^{*}$ & $0,363^{*}$ & $(0,87)$ \\
\hline
\end{tabular}

Not: İlk kolonda parantez içindeki sayılar ilgili değişkenin standart sapma değeridir. Diyagonalde yer alan parantezler ise, kullanılan ölçeklerin Cronbach Alpha katsayılarını göstermektedir. Tabloda * işaretli olarak gösterilen korelasyon katsayıları 0,001 düzeyinde anlamlidir.

\section{Yönetici ve İşgören Tutumlarına Dair Karşılaştırmalı Bulgular ve Öneriler}

Elde edilmesi hedeflenen amaç doğrultusunda örneklem bir kez işgören, bir kez de yöneticiler için çok değişkenli regresyon analizine tabi tutulmuştur. Analizlerin bulguları iki grup için farklı olarak yordanmıştır. Konaklama sektöründe daha önce gerçekleştirilen bir diğer araştırma da işgören ve yönetici iş tutumlarının birbirinden farklı olabileceğini ve ayrılma niyetini belirleyen değişik unsurların olabileceğini gösteren araştırmaları destekler niteliktedir (ör. Lu, Lu, Gursoy ve Neale, 2016). Çalışmamızın bulguları işgörenlerin işyerinden ayrılma niyetinin öncülerden birisinin duygusal bağlllık olduğu göstermiştir (Tablo 3). Bunu takiben işverene güven ve daha düşük düzeyde de olsa dağıtım adaleti ile eğitimin de etkisinin olduğu neticesine varılmıştır $\left(R^{2}=0,39, p<0,01\right)$. Bulgular, işgörenlerin işten ayrılma niyetlerini belirleyen, kısaca işi bırakma kararlarını etkileyen birden fazla kıstas olduğuna işaret etmektedir. Öne çıkan faktör olarak duygusal bağllık, işgörenlerin çalıştıkları kurumların sorunların kendi sorunları gibi hissetme, kuruma karşı güçlü bir aidiyet duyma ve kendilerini bir ailenin parçasıymış gibi hissetme olarak düşünülebilir. Duygusal bağlılıkları yüksek olan işgörenler çalıştıkları kurumun bir üyesi olmaktan memnuniyet duymaktadırlar (Chew ve Wong, 2008) ve bu nedenle ayn işyerinde kalmayı tercih etmektedirler.

Bahsedilen durumda işgörenlerin aidiyet duygularını artırmak için İK yöneticilerine bu hissi destekleyici yönetim uygulamaları geliştirmeleri tavsiye edilebilir. Geleneksel olarak örgütler, işgörenlerin bağlılıkları artırmak için ücret ve yan menfaatleri ve terfi olanaklarını kullanırlar. Ancak diğer sektörlerde olduğu gibi otellerde de son yıllarda yapılan araştırmalar kişisel gelişim olanaklarının ve verilen örgütsel desteğin işgören bağlllı̆̆ını artırmakta önemli bir rol oynayabileceğini göstermektedir (Chew ve Wong, 2008; Kaplan ve Adem, 2012). İşgörenlerin çalıştıkları kuruluşun kendilerini örgütsel olarak desteklediğini algıladıklarında duygusal olarak bağlandıkları, işyerine güven duydukları ve dolayısıyla işyeri tatminlerinin arttı̆̆ı ve bu nedenle örgütsel vatandaşlık davranışları sergiledikleri ve işyerinden ayrılma niyetlerinin azaldığı da öne sürülmektedir (Inelmen vd., 2010; Paillé, Bourdeau ve Galois, 2010). Çalışmada, işgörenler için işyerinden ayrılma niyetini açıklayan nedenlerin içinde duygusal bağlılığın hemen arkasından işverene güven'in gelmesi iki değişkenin arasındaki yakın bağı vurguladığı gibi, aralarındaki korelasyon da oldukça yüksektir $(\mathrm{r}=0,64, \mathrm{p}<0,001)$. 
Tablo 3. İşyerinden Ayrıma Niyetinin İşgören Gruplarına Göre Yordanması

\begin{tabular}{|l|c|c|}
\hline & İşgörenler (n1=707) & Yöneticiler (n2=137) \\
\hline Cinsiyet & $-0,024$ & $-0,029$ \\
\hline Yaş & $-0,036$ & $-0,071$ \\
\hline Ĕgitim düzeyi & $0,106^{*}$ & 0,093 \\
\hline İşverene Güven & $-0,242^{* *}$ & $-0,452^{* *}$ \\
\hline Duygusal Bağlllık & $-0,368^{* *}$ & $-0,183$ \\
\hline Dağıtım Adaleti & $-0,099^{*}$ & $-0,036$ \\
\hline Adj. $\mathbf{R}^{2}$ & $0,393^{* *}$ & $0.347^{* *}$ \\
\hline
\end{tabular}

Not: Tabloda gösterilen değerler standardize beta katsayılarıdır. Bulguların, ${ }^{*}$ işaretli olanları $0,01,{ }^{* *}$ ile işaretli olanları 0,001 düzeyinde anlamlıdır.

Araştırmaya katılan otellerin İK departmanlarına uygulanan anketlerin bulguları incelediğinde ise, işletmelerin işgören bağlılığını artırmak için sıklıkla ücret ve yan menfaatleri (\%71), daha sonra ise eğitim olanaklarını (\%69) ve yetkilendirmeyi (\%48) kullandıkları belirlenmiştir. Kişisel gelişim olanaklarının bir parçası olarak, kariyer yönetimi otellerde bağlılığı artırmak için gerilerde kalmakta ve sadece örneklem içindeki 14 otelde bulunmaktadır $(\% 37,8)$. Ancak kariyer yönetimi, kişiye özel kariyer haritası çizilmesi, koçluk ve mentörlük gibi uygulamalarla otel işgörenlerine önemli bir değer ifade edebilmekte ve destek olabilmektedir (Chew ve Wong, 2008; Walsh ve Taylor, 2007). Otellerde yapılandırılmış mentörlük programlarının geliştirilmesi liderler ve işgörenler arasındaki bağları kuvvetlendirecek ve işgörenlerin performansına katkıda bulunacaktır (Kim ve Koo, 2017).

Konaklama sektöründe eğitim düzeyi yüksek işgörenler aktif olarak kendi kariyerlerini yönetmekte ve kendilerine ilerleme olanakları sunan pozisyonları aramaktadırlar (Walsh ve Taylor, 2007). Araştırmanın bulguları işgörenlerin eğitim düzeyleri yükseldikçe işyerinden ayrılma niyetinin artığına işaret etmektedir. Dolayısıyla yönetiminin eğitim düzeyi yüksek işgörenleri işletmede tutabilmek için onların gelişmeye yönelik ihtiyaçlarına cevap vermesi ve onları kişisel gelişim olanakları ile desteklemesi önemlidir. Otel işletmelerinde kişisel gelişim olanaklarına başlangıç olarak koçluk ve mentörlük uygulamalarına başlanılması önerilebilir (McGuire ve Kissack, 2015). İşyerinde koçluk yapılandırılmış yöntemler aracılığıyla olduğu gibi, yapılandırılmamış olarak iş üzerinde de verilebilir (Ellinger, 2015). İşyerinde koçluk hat yöneticisi, İK yöneticileri veya diş danışmanlar tarafından sağlanabilir. Koçluk sonucunda işgörenlerin öğrenme hızlarının iyileştiği, performanslarının artığı, yüksek motivasyon sergiledikleri, yüksek iş tatminine sahip oldukları ve kuruma olan bağlılıklarının artığı gözlemlenmiştir (Ellinger, 2015). Koçluk yapan yöneticin aktif dinleme, analiz etme, mülakat yapabilme, sorgulama ve gözlemleme yetkinliklerini kullanması gerekmektedir. Bu nedenlerle özellikle hat yöneticilerinin yetkinliklerinin eğitimler aracılığıyla geliştirilmesi (Park, Yang ve McLean, 2008) ve eğitimleri İK birimlerinin planlanması önerilebilir.

Mentörlük tecrübeli, bilgili ve işgörene göre daha yüksek rütbede bulunan mentör tarafından birebir gerçekleştirilen ve kariyer gelişimi konusunda destek ve gelişim sağlayan bir uygulamadır (Ellinger, 2015). Mentörlük de koçlukta olduğu gibi İK tarafından planlı bir uygulama olarak ele alınabilir. Özellikle de çoklukla gençlerin çalıştığı konaklama sektöründe yapılandırılmış olarak uygulanan mentörlüğün, işgörenleri işyerinde uzun süre kalmaya istekli olmaları konusunda etkili olacağı önerilebilir. İşgörenler açısından kariyer hedeflerinin ve performanslarının yöneticileri ile karşılıklı görüşülmesi ve gelişim planlarının geliştirilmesi işgörenlerin performanslarını iyileştirmeleri için de faydalıdır. Bazı İK uygulamaları ancak 
birbirlerini desteklerinde etkilidir ve yöneticilerin desteği uygulamalarının etkinliğini artırmaktadır (Hu vd., 2021). Karşılıklı görüşmeler işgören-yönetici ilişkilerini geliştirecek ve işyerine bağlllı̆̆1 da destekleyecektir (Kim ve Koo, 2017).

Kişisel gelişim olanaklarını ile ilişkili ve kariyer yönetimi ile birbirini takip eden İK yönetim işlevi ise performans yönetim süreçleridir. Performans yönetim sistemi sonucunda gerçekleştirilen değerlendirme görüşmesi işgörene beklenen performans ile gerçekleşen arasındaki farkları bildirir ve kendisini geliştirmesi gereken yönleri işaret eder. Araştırmanın bulguları örneklem içinde bulunan 14 otel işletmesinde $(\% 37,8)$ yapılandırılmış performans yönetim sistemi olduğunu ve karşılıklı performans değerlendirilmesi yapıldığını göstermektedir. Ayrıca işgörenlerin çoğunluğuna (\%80-\%100) performans değerlendirmesi uygulayan otellerin sadece dörtte biridir. Araştırmaya dâhil edilen otellerin önemli bir bölümünün kariyer ve performans yönetimi süreçlerinde geride olduğu düşünüldügüunde, öncelikle etkin ve şeffaf bir performans yönetimi uygulamasının yerleştirilmesi önerilebilir. Bu şekilde geliştirilmiş performans yönetim sistemi ve buna bağlı kariyer yönetim sistemi tüm işgörenlerin memnuniyeti artıracak (Kuşluvan ve Kuşluvan, 2005) ve işverene güven duygusunu da pekiştirecektir.

\section{Yönetici Bulguları, Değerlendirmesi ve Öneriler}

İşgörenlerden farklılaşan biçimde, aynı regresyon modeli yöneticiler için uygulandığında işyerinden ayrılma niyetinin yegâne kaynağının işverene güven olduğuna işaret etmektedir $\left(\mathrm{R}^{2}=0,35, \mathrm{p}<0,01\right)$. İşverene güven, işverenin ve yöneticilerin kendilerine dürüst olacağına ve verdiği sözleri yerine getireceğine ve arkasında duracaklarına işgörenlerin inançları olarak tanımlanabilir (Gilbert ve Tang, 1998, Demircan ve Ceylan, 2003). Araştırmada ölçüldüğü şekli ile yöneticiler kendilerine istikrarlı ve tutarlı davranıldığına inandıklarında çalıştıkları işyerinde kalmayı tercih etmektedirler. İşverene güvenin beslenmesinde öne çıkan yönetimsel uygulamanın açı bir iletişim ve bilginin paylaşılması olduğu öne sürülmektedir (Gilbert ve Tang, 1998; Holland, 2014). Yöneticilerin iş yerinden ayrılma niyetini etkileyen tek bir faktörün ortaya çıkışı, duygusal bağlılık, dağıtım adaleti, yaş, cinsiyet ya da eğitimin belirleyici olmaması, kendi içinde önemli bir bulgudur. Özellikle konaklama sektörü yöneticilerini örgütte tutmak açısından, işverenlerin Schoorman Mayer ve Davis'in (2007) Entegre Güven Model'inde ortaya koydukları gibi, dürüstlükleri, işle ilgili yetkinliklerini sergilemeleri ile müşfik ve iyi niyetli (benevolant) davranışlar yoluyla güven kazanmalarının gerekliliğine işaret etmektedir.

Araştırmaya katılan otel işletmelerinin hedef ve planları yapılandırılmış yollardan (toplantı, dergi, Intranet, vb.) işgörenlerle paylaşımı incelendiğinde otellerin bu konuda diğer İK işlevlerine göre daha başarılı olduğu görülmektedir $(\% 68,4)$. Diğer taraftan otellerin paylaşımlarda seçici olduğu ve örneklemin sadece üçte birinin hedef ve planları tüm işgörenleri ile açık ve doğru bir şeklide paylaştığı anlaşılmaktadır. Otellerde işgörenler ve yöneticiler arasındaki yakın çalışma ortamı değerlendirildiğinde, bilgi paylaşımının bir bölümünün yapılandırılmamış yollardan da gerçekleştiğini varsaymak mümkündür. İşerene güven ile ayrılma niyeti arasındaki ilişki düşünülerek otel yönetimlerine tüm işgörenleri ile zamanlı, açık, doğru, kaliteli (Demircan ve Ceylan, 2003) bilgiyi paylaşmaları gerektiğini hatırlatmak önemli olacaktır.

\section{Otel Kategorilerine Bağlı Bulgular, Değerlendirme ve Öneriler}

Değişik otel kategorilerinde bulunan işgören ve yöneticilerin işyerinden ayrılma niyetini ANOVA analizi ile incelendiğinde ortaya çıkan bulgular anlamlı farklara işaret etmektedir. Araştırmada yer alan üç yıldız kategorisindeki otel işletmelerinde işgörenlerin işyerinden ayrılma niyetinin 
diğer kategorilerdeki işgörenlerin hepsine klyasla istatiksel olarak anlamlı düzeyde düşük olduğu, diğer kategoriler olan dört, beş yıldızlı ve butik otel işgörenlerinin aralarında ise istatistiksel olarak anlamlı farklar olmadığı ve her üç kategoride işgörenlerin homojen bir alt grup oluşturdukları görülmüştür $(\mathrm{p}<0,05)$. Dört ve beş yıldızlı otellerin İK sistemlerini inceleyerek üç yıldızlı otellerde işgörenlerin neden diğer kategorilere göre daha fazla bulundukları işletmelerde devam etmek istediklerine açıklamada bulunmak mümkün olacaktır.

Otellerde İK'nın yönetim şekli, büyüklük, yıldız sayısı, yabancı bir otel zincirinin parçası olması gibi kıstaslara bağlı olarak farklılık gösterir. Öncelikle uluslararası ve yıldızı yüksek otellerde belirli misafir hizmet standartlarını yakalayabilmek adına yönetim sistemleri oldukça katı ve yapılandırılmıştır. İşgörenlerin iş tanımları önceden belirlenmiştir, esneklik çok düşüktür ve kendilerinden daha "profesyonel" davranışlar sergilenmeleri beklenir (Haynes ve Fryer, 2000). $\mathrm{Bu}$ doğrultuda işgörenler iş tanımlarına bağlı olarak eğitimler alırlar ve misafir ilişkilerinde kendilerinden beklenen kontrollü davranışları yerine getirirler. Kavramsal çerçeve bölümünde de anlatıldığı üzere, büyük ve çokuluslu otellerin İK sistemlerinde standartlaşmaya gittiği ve merkezde kullanılan ve diğer İK uygulamalarına kıyasla daha yüksek performans getirdiği düşünülen sistemlerin kabul edildiği söylenebilir. Araştırma kapsaminda İK birimlerinden toplanan verileri incelediğinde dört ve beş yıldızlı otellerin gerçekten de daha yapılandırılmış İK uygulamalarına sahip olduğu belirlenmiştir. Araştırma bulgularına göre neredeyse tüm beş yıldızlı otellerde yazılı IKK stratejisi bulunmaktadır ve iş tatmin anketi, işe alıştırma programı ve kadro planlaması uygulanmaktadır. Ancak üç yıldızlı otellerin ancak yarısından azında bu uygulamalar bulunmaktadır.

Hizmet sektörü üretim sektöründen farklı olarak üretim ve tüketim aynı mekânda ve aynı zaman dilimi içinde gerçekleşir ve bu nedenle hataların anında düzeltilmesi önemlidir. Özellikle misafir ile doğrudan ilişki içinde olan işgörenlerin hizmet kalitesini artırmaya yönelik davranışlar sergilemeleri ve gerektiğinde iş tanımın dışına çıkarak davranmaları misafir memnuniyetine olumlu yansıyacaktır. Buna paralel olarak hizmet kalitesinin iyileştirilmesine yönelik işgörenlerin görüşleri de çok değerlidir. Esasında konaklama sektörü, işgörenlere seslerini duyurabilecekleri birçok fırsat yaratır (Raub ve Robert, 2013) ve bu geribildirimlerin değerlendirilmesi hizmet kalitesine de olumlu yansıyacaktır. Bu bulguların eşliğinde, daha büyük ve yıldız sayısı yüksek otellerin yönetimlerine işgörenin sesini duyurabileceği ve katılımını artırabileceği, zaman zaman misafir memnuniyeti artırmak adına esneklik sağlayabilecekleri uygulamaların geliştirilmesi önerilebilir. Ayrıca sendikalaşma oranının düşük olduğu otellerde, ki bu sektörde oldukça yaygın bir durumdur (Yorgun, Keser ve Yılmaz, 2009), işgörenlerin sesini duyurabileceği mekanizmaların geliştirilmesi daha da önem kazanmaktadır (Hatipoglu ve İnelmen, 2018). Katılımı artırıcı uygulamaların içinde düzenli takım toplantıları, problem çözme grupları ve kalite çemberleri sayılabilir.

Yukarıda gösterildiği üzere, çok katmanlı yönetim seviyeleri işgörenlerin bazen yönetime seslerini duyurmakta, memnuniyetsizliklerini bildirmekte ve geri bildirim almakta zorlanmaları ile bulgulanır. Buna karşın daha küçük otel işletmelerinde işgören ve yönetici bazen de otel sahibi çok yakın temas içindedir ve bu nedenle günlük iletişim daha kolay gerçekleşebilmektedir. Üç yıldızlı otellerdeki işgörenlerin işten ayrılma niyetinin neden diğerlerine göre daha düşük olduğunu sorgulandığında işgörenlerin kendi yöneticileri ile ilgili düşüncelerini de incelemek anlamlı olacaktır. Tüm işgörenlerden toplanan bir diğer değişken olan lider-üye etkileşimini ANOVA analizi ile incelendiğinde anlamlı bir farklılık olduğu $(p<0,05)$ ve üç yıldızlı otellerde işgörenlerin kendi yöneticileri ile olan etkileşimden diğer otel kategorilerine (ortalama=3,68) göre en memnun grup oldukları (ortalama=3,87) saptanmıştır, bu bulgu da önceki açıklamaları 
destekler niteliktedir. Benzer şekilde, Konya ilinde faaliyet gösteren otel işletmelerinde uygulanan bir çalışmada sektör işgörenlerinin liderleri hataları affedici ve katılımcı yönetim prensiplerini uyguladıklarında daha olumlu örgütsel davranış ve tutumlar sergiledikleri görülmüştür (Çelik, 2018).

Otellerde hizmet kalitesi artıkça odabaşına düşen işgören sayısı da artmaktadır. Çalışmada beş yıldızlı oteller için bu oran 0,92, dört yıldızlı oteller için 0,51, üç yıldızlı oteller için 0,34 ve butik oteller için 0,61 olarak bulunmuştur. İşgören sayısının göreceli olarak daha fazla olduğu durumlarda, bir işi birden fazla kişi yapabilmekte veya iş daha küçük parçalara bölünebilmektedir. Üç yıldızlı otellerde işgören sayısı göreceli olarak daha düşük olduğu için işgören aynı anda birkaç işi yapabilmekte ve dolayısıyla yeteneklerini farklı alanlarda geliştirme olanağı bulabilmektedirler (örn. ön büro işgöreninin aynı anda rezervasyona ve satışa destek vermesi gibi).

Kariyerlerinde ilerlemek isteyen kişiler için sürekli öğrenmek ve gelişmek önemlidir. Bununla birlikte daha fazla işten aynı anda sorumlu olan işgörenler, işleri ile ilgili daha fazla özerkliğe de sahip olmaktadırlar. İşyerlerinde yatay ve dikey olarak görev alanlarının genişletilmesi söz konusu olduğunda işgörenler hem işlerinden sorumluluk duyarlar hem de işleri üzerinde daha fazla etkiye sahip olurlar (Walton, 1985). Üç yıldızlı otellerde işgörenlerin kendilerini farklı görevlerde geliştirme olanağı bulmaları ve işleri üzerinde etkiye sahip olmaları onları aynı işyerinde çalışmaya iten sebeplerden bazıları olarak öne sürülebilir (He vd., 2021). Bu noktadan çıkarak yıldız sayısı yüksek olan büyük otellerin İK yönetimlerine işgörenlerin özerkliklerini artırıcı (örn. yatay ve dikey görev alanlarının genişletilmesi gibi) ve öğrenme olanakları yaratan (iş rotasyon programları gibi) faaliyetleri uygulamaları önerilebilir. Otellerde yetkinlik artırımı işgörenlerin işlerini daha anlamalı bulmalarını sağlayacak ve işe adanmışlıklarını destekleyecektir (He vd., 2021). Bu konuda dikkat edilmesi gereken önemli nokta, yatay ve dikey görev alanları geliştirilirken bunu maliyetleri düşürmek veya kontrolü artırmak adına değil, işgörenlerin katılımının sağlanmasına yönelik yapılması gerektiğidir. Aksi taktirde bu türlü algılanan girişimlerin, işgörenlerde işverenlerine karşı güvensizlik oluşturabildiği öne sürülmüştür (Inelmen ve Hatipoglu, 2018). Sektörde genel eğilim bir taraftan işgörenlerin sorumlulukları artırırken bir taraftan da görev tanımları yok olan işgörenleri işten çıkarmak olarak sonuçlanmaktadır (Hoque, 2000).

Çalışma kapsamında işten ayrılma niyetini sorgularken, otel kategorilerine göre işgören ve yöneticilerin de karşılaştırılması yapıldığında, her otel kategorisi için benzer şekilde yöneticilerin işyerinden ayrılma niyetinin işgörenlere nazaran daha düşük olduğu ve bu farkların istatistiksel olarak anlamlı bulunduğu belirlenmiştir $(\mathrm{p}<0,05)$. İki grup arasındaki farklılık aynı işyerinde çalışma sürelerinin ortalamaları ile uyumludur. İşgörenlerin bir bölümü oteldeki mesleğine geçici bir iş olarak bakabilmekte ve sadece işyerini değil sektörü de kolaylıkla bırakabilmektedir. Ancak yönetici pozisyonuna gelenler sektöre ve işyerine daha uzun emek verdikleri için ayrılmalarının kendileri için maliyeti daha fazla olacaktır. Bu bulgunun ilişkili olduğu diğer bir konu ise lider-üye etkileşimidir. ANOVA analizi bulguları anlamlı bir farklılığa işaret etmiş $(p<0,01)$ ve beklenen üzerine yönetici grubunun (ortalama=3,96) kendi yöneticileri ile olan ilişkilerinden işgörenlere (ortalama=3,62) kıyasla daha memnun olduğunu sergilenmiştir. Bu memnuniyet her iki işgören grubu içinde en çok memnuniyet üç yıldızlı otellerde olmuştur.

Yukarıda bahsedilen bulgular ışığında işgörenlerin yakın ilişkide bulundukları hat yöneticileri ile olan ilişkileri daha yakından incelenmelidir. İnsan yönetiminde yeni yaklaşım her yöneticin IK yöneticisi gibi hareket etmesi gerektiğidir. Hat yöneticilerinin insan yönetimi hakkında 
yetkinlikleri değerlendirilmelidir. Belirlenen eksikler arasında güven oluşturma, iletişim kurma ve kişisel gelişime katkıda bulunma gibi eksikler varsa bu konuda hat yöneticilerini geliştirici destekler verilmelidir (örn. koçluk eğitimi). Hat yöneticilerin işletmenin İK prensiplerini anlaması ve en etkin şekilde uygulaması gerekmektedir (Hoque, 2000). Araştırma hat yöneticilerin etkin İK uygulamalarını kullanarak işgörenlerin iş yerinden ayrılma niyetini azaltabileceğini ileri süren çalışmaları desteklemiştir.

\section{TARTIŞMA ve SONUÇ}

Çalışmanın amacı otel kategorileri ve işgören gruplarına bağlı olarak işten ayrılma niyetinin kaynaklarının farklılaşıp, farklılaşmadığına dair İK stratejileri belirlemektir. Öncelikle çalışmanın bulgularını diğer çalışmalardan farklı ve değerli kılan verilerin üç farklı kaynaktan toplanmış oluşudur. Varış noktasını bütünüyle temsil edebilecek bir örneklem elde etmek yoluyla İstanbul ili içinde şehir otelciliği yapan ve TÜROB üyesi olan 38 otelin işgörenlerinden, yöneticilerinden ve İK departmanlarından anket yolu ile veri toplanmıştır.

Çalışmanın bulguları ve değerlendirmesi teorik bilgi birikimine katkı sağlamaktadır. Birinci katkısı yüksek performanslı insan kaynakları yönetimine katkısıdır. Daha önceki çalışmalar İK uygulamaların daha yüksek performans yakalamak adına işgörenlerin teknik bilgilerini ve yetkinliklerini artırabileceğini ve olumlu örgütsel davranışlar sergilemelerine sebep olabileceğini göstermişlerdir (Boxall ve Purcell 2007; Gürlek, 2020, He vd., 2021, Karadas ve Karatepe 2019, Macky ve Boxall 2007). Otellerde yürütülen bu çalışmanın bulguları ise otellerin yüksek performanslı İK uygulamalarını etkin kullanmadıklarını göstermiştir. Yüksek performanslı İK uygulamaların içinde işgören yetkinliklerinin artırılması, karar süreçlerine katılım, açık iletişim, kar paylaşımı ve performans değerlendirmeleri bulunmaktadır. Çalışmanın bulguları doğrultusunda otellerin komuta ve kontrole dayalı yönetim yerine işgörenlerin işyerine güvenini, bağlığını ve katılımını artıracak uygulamaları tercih etmeleri önerilmiştir (He vd., 2021; Karadas ve Karatepe, 2019).

Araştırmanın teorik alanda diğer bir katkısı ise bağlamsal yaklaşım alanınadır. Araştırmanın bulguları otel kategorilerine göre işten ayrılma niyetinin için en düşük üç yıldızlı otel işletmelerinde olduğunu göstermiştir. Kavramsal çerçeve ve bulgular dört ve beş yıldızlı otellerin daha fazla yapılandırılmış İK yöntemleri kullandığına işaret etmiştir. Buna rağmen üç yıldızlı otellerdeki işgörenler diğerlerine göre daha fazla aynı iş yerinde devam etmek istemektedirler. Dolayısıyla bulgular bizlere standart ve yapılandırılmış İK uygulamalarının tek çözüm olarak görülmemesi ve geliştirilmesi gerektiğini hatırlatmaktadır. İK alanında bağlamsal yaklaşıma göre bir kuruma veya bir kültüre uygun olan uygulama mutlak iyi değildir. Bu nedenle iyileştirme yaparken İK yöneticileri işgörenlerin homojen olmadığını, farklı özellikleri, davranışları ve istekleri olduğu göz önünde tutmalıdırlar. Tek tip uygulamalar ve varsayımlar gittikçe farklılaşan işgücüne uymayacaktır. Kişisel gelişim olanakları katılımcı uygulamalar ve özerkliği artırıcı esneklik faydalı olacaktır.

Bağlamsal yaklaşımı destekleyen araştırmanın diğer bulgular ise işgören ve yöneticiler arasındaki farklılıklardır. Kavramsal çerçevenin de desteklediği üzere (Cho vd., 2006; Lu vd., 2016), araştırma işgörenlerin ve yöneticilerin ayrılma niyetlerini belirleyen farklı değişkenler olduğunu tespitini desteklenmiştir. Bulgular bağlamsal yaklaşım ile değerlendirildiğinde, bu bulgu bir işletmenin içinde işgörenlerin ve yöneticilerin ayrılma niyetlerini açıklayan nedenlerin farklı olabileceğini açıklamaya yardım eder. İşörenlerin işten ayrılma niyetini duygusal bağ lılık, işverene güven, dağıtım adaleti ve eğitim belirlerken, yöneticilerin ayrılma niyetinin yegâne 
belirleyici değişkeni işverene güven olmuştur. Konaklama sektöründe işverene güven tüm işgörenler için geliştirilmesi gereken bir konudur, ancak bununla birlikte işgörenlerin aidiyet hislerinin de artırılması işletmede daha uzun süre kalmalarını sağlayacaktır. Bu bulgularda da görüldüğü üzere tüm işgören gruplarına aynı şekilde uygulanan İK uygulamaları uzun vadede başarılı olmayacak ve beklenen olumlu davranış ve tutumları getirmeyecektir. Sürücü vd., (2019) bulguları misafir memnuniyeti ve güvenin oluşmasında, amaca yönelik davranışları özümsemiş otel işgörenlerinin seçiminin, oryantasyonunun, motivasyonunun ve eğitiminin önemine işaret etmektedir. Dolayısıyla, İK'nın işgörenleri iyi tanıması ve uygun yönetim prensiplerini belirlemesi gerekmektedir.

Çalışmada son olarak yöneticilerin ayrılma niyetinin işgörenlere göre daha düşük olduğu ve ayrıca kendi yöneticileri ile ilişkilerinden daha fazla memnun oldukları bulunmuştur. Bu bulgu işgörenlerin devir hızının daha yüksek olması ile uyumludur. Nihayetinde, işgörenler kendi yöneticileri ile ilişkilerinden daha az memnundurlar. Bulgular hat yöneticilerinin işgörenlerin ayrılma niyetlerini belirleyici olarak önemini destekler durumdadır. Bu nedenle, otellerde IKK birimlerine hat yöneticilerini, İK uygulamaları alanında daha fazla geliştirmeleri ve destek vermeleri önerilmektedir.

$\mathrm{Bu}$ araştırmanın belirli sınırlılıkları ve gelecek araştırmalar için önerileri bulunmaktadır. Araştırma kesitsel araştırma tasarımına uygun olarak yürütülmüştür. Bu nedenle, incelediği değişkenlerin veri toplanması sonrasında gösterdikleri değişkenliği hakkında bulgu sunmamaktadır. Gelecek çalışmalar farklı aralıklarla veri toplayarak boylamsal bir araştırma gerçekleştirebilirler. Bu çalışma hizmet sektörüne örnek olarak otel işgörenleri ve yöneticilerinden veri toplanarak gerçekleştirilmiştir. Bundan sonraki çalışmalar konaklama sektöründe faaliyet gösteren diğer işletme türlerine veya hizmet sektörlerinde bulunan işgörenlere odaklanabilirler. Ayrıca bu çalışma sadece İstanbul ilinde faaliyet gösteren şehir otel işletmelerinde yürütülmüştür. Dolayısıyla araştırmanın sonuçlarını genelleştirmek doğru değildir. Diğer araştırmalar farklı şehirlerde yer alan otel işletmelerinden veri toplanarak yapilabilir.

\section{KAYNAKÇA}

Alvarez, M.D., and Hatipoğlu, B. (2014). Nationality Differences in User-Generated Reviews in the Hospitality Industry. A. G. Woodside, ve M. Kozak içinde, Tourists' Perceptions and Assessments Advances in Culture, Tourism and Hospitality Research, 8, 23-29. Emerald Group Publishing Limited.

Aycan, Z. (2006). Human resource management in Turkey. İçinde Managing Human Resources in the Middle East. P. S. Budhwar and K. Mellahi (Der.). Psychology Press, 160-179.

Baum, T. (2007). Human resources in tourism: Still waiting for change. Tourism Management, 28(6), 1383-1399.

Bingöl, D., Aydoğan, E., Şenel, G., ve Erden, P. (2011). Cam tavan sendromu ve kadınların hiyerarşik yükselmelerindeki engeller: TC. Enerji ve Tabii Kaynaklar Bakanlığı Ankara Merkez Teşkilatı örneği. Dokuz Eylül Üniversitesi İ̧̧letme Fakültesi Dergisi, 12(1), 115-132.

Boxall, P. and Macky, K. (2009). Research and theory on high-performance work systems: Processing the high-involvement stream. Human Resource Management Journal, 19(3), 3-23.

Chand, M. (2010). The impact of HRM practices on service quality, customer satisfaction and performance in the Indian hotel industry. The International Journal of Human Resource Management, 21(4), 551-566. 
Chew, Y. T. and Wong, S.K. (2008). Effects of career mentoring experience and perceived organizational support on employee commitment and intentions to leave: A study among hotel workers in Malaysia. International Journal of Management, 25(4), 692-700.

Cho, S., Woods, R. H., Jang, S.S. and Erdem, M. (2006). Measuring the impact of human resource management practices on hospitality firms' performances. International Journal of Hospitality Management, 25(2), 262-277.

Colquitt, J.A. (2001). On the dimensionality of organizational justice: A construct validation of a measure. Journal of Applied Psychology, 86(3), 386-400.

Çelik, N. (2018). The Effect of Accommodation Enterprises Workers' Perception of Servant Leadership on Organizational Identification: The Case of Konya (Konaklama İşletmeleri Çalışanlarının Hizmetkar Liderlik Algilarinin Örgütsel Özdeşleşme Üzerine Etkisi: Konya İli Örneği). Mehmet Akif Ersoy Üniversitesi İktisadi ve İdari Bilimler Fakültesi Dergisi. 5(3), 765-782.

Deery, M., and Jago, L. (2009). A framework for work-life balance practices: Addressing the needs of the tourism industry. Tourism and Hospitality Research, 9(2), 97-108.

Demircan, N., ve Ceylan, A. (2003). Örgütsel güven kavramı: Nedenleri ve sonuçlar. Yönetim ve Ekonomi: Celal Bayar Üniversitesi İktisadi ve İdari Bilimler Fakültesi Dergisi, 10(2), 139-150.

Dowling, P.J., Festing, M., and Engle, A.D. (2013). International Human Resource Management. Cengage Learning: Singapore.

Ellinger, A. D. (2015). Coaching ve Mentoring. R.F. Poell, S. Rocco, ve G. L. Roth içinde, The Routledge Companian to Human Resource Development, 258-271. Abington: UK: Routledge.

Erdoğan Morçin, S. ve Coşkun, B. (2020). Liderle özdeşleşme ve örgütsel özdeşleşmenin işten ayrılma niyetine etkisi: Önbüro çalışanları üzerine bir araştırma. Türk Turizm Araştırmaları Dergisi, 4(3), 1908-1922.

Domínguez-Falcón, C., Martín-Santana, J.D. and De Saá-Pérez, P. (2016). Human resources management and performance in the hotel industry: The role of the commitment and satisfaction of managers versus supervisors. International Journal of Contemporary Hospitality Management, 28(3), 490-515.

Gilbert, J. A., and Tang, T. L. (1998). An examination of organizational trust antecedents. Public Personnel Management, 27(3), 321-338.

Graen, G. B., and Uhl-Bien, M. (1995). Relationship-based approach to leadership: Development of leader-member exchange (LMX) theory of leadership over 25 years: Applying a multi-level multi-domain perspective. Leadership Quarterly, 6(2), 219-247.

Gürlek, M. (2020). Yüksek performanslı insan kaynakları uygulamaları hizmet odaklı örgütsel vatandaşlık davranışını nasıl etkiler? İş tutumlarının aracılık rolü. İş ve İnsan Dergisi, 7(1), 59-76.

Harris, H., Brewster, C. and Sparrow, P. (2003) International Human Resource Management. CIPD Publishing: Londra.

Haynes, P., and Fryer, G. (2000). Human resources, service quality and performance: a case study. International Journal of Contemporary Hospitality Management, 12(4), 240-248.

Hatipoğlu, B., Alvarez, M.D., Inelmen, K. ve Ünalan, D. (2013). İstanbul Otellerinin $360^{\circ}$ derece Değerlendirmesi Araştırma Proje Raporu 2013. TUROB, 1-95. 
Hatipoglu, B., and Inelmen, K. (2018). Demographic diversity at the workplace and its impact on employee voice: The role of trust in the employer. The International Journal of Human Resource Management, 29(5), 970-994.

He, J., Morrison, A.M. and Zhang, H. (2021). How high-performance HR practices and LMX affect employee engagement and creativity in hospitality. Journal of Hospitality $\mathcal{E}$ Tourism Research, DOI: 1096348021996800.

Holland, P. (2014). Employers and Voice içinde Handbook of Research on Employee Voice, (Der.) A. Wilkinson, J. Donaghey, T. Dundon ve R. B. Freeman, 135-154. UK: Edward Elgar Publishing Ltd.

Huselid, M.A. (1995). The impact of human resource practices on turnover, productivity, and corporate financial performance. Academy of Management Journal, 38(3), 635-672.

Hoque, K. (2000). Human Resource Management in the Hotel Industry. New York, NY: Routledge.

Inelmen, K., Özgümüş, E., Parlak, G., Salti, N., and Sarıot, H. (2010). The effects of career commitment, organizational commitment and trust on organizational citizenship behaviors of hospital and hotel employees. International Journal of Business, Management and Economics, 11-12 (4), 12-25.

Inelmen, K. and Hatipoglu B. (2018). Hotel guests' satisfaction with employees in Istanbul and Barcelona. İçinde M. Kozak ve N. Kozak (Editörler), Tourist Behavior: An Experiential Perspective, Ch. 5, 65-80. Cham, İsviçre: Springer International Publishing AG.

Kaplan, M., ve Adem, Ö. (2012). Algılanan örgütsel destek ile örgütsel bağlllık arasındaki ilişkinin analizi: Otel işletmelerinde bir uygulama. Süleyman Demirel Üniversitesi İktisadi ve İdari Bilimler Fakültesi Dergisi, 17(1), 387-401.

Karadas, G., and Karatepe, O.M. (2019). Unraveling the black box: The linkage between highperformance work systems and employee outcomes. Employee Relations, 41(1), 67-83.

KaragüL, M., ve Dündar, S. (2006). Sosyal sermaye ve belirleyicileri üzerine ampirik bir çalışma. Akdeniz III BF Dergisi, 12, 61-78.

Karatepe, O.M. (2013). High-performance work practices and hotel employee performance: The mediation of work engagement. International Journal of Hospitality Management, 32, 132-140.

Karriker, J.H. and Williams, M.L. 2009. Organizational justice and organizational citizenship behavior: A mediated multifoci model. Journal of Management, 112-135.

Kazlauskaite, R., Buciuniene, I. and Turauskas, L. (2006). Building employee commitment in the hospitality industry. Baltic Journal of Management, 1(3), 300-314.

Keser, A. and Dursun, S. (2017). Analyzing the Effects of Perceived Job Insecurity on Job Satisfaction and Intention to Leave. Paradoks Ekonomi, Sosyoloji ve Politika Dergisi, 13(1), 1-14.

Kırant Yozcu, Ö. (2020). Otel işletmesinde ilişki yönetimi bağlamında çalışan ilişkilerine yönelik bir araştırma. Türk Turizm Araştırmaları Dergisi, 4(4): 3289-3310.

Kim, H. J., Tavitiyaman, P., and Kim, W.G. (2009). the effect of management commitment to service on employee service behaviors: The mediating role of job satisfaction. Journal of Hospitality \& Tourism Research, 33(3), 369-390.

Kim, M.S., and Koo, D.W. (2017). Linking LMX, engagement, innovative behavior, and job performance in hotel employees. International Journal of Contemporary Hospitality Management, 29(12), 3044-3062. 
Koçel, T. (1989). İşletme Yöneticiliği. İstanbul Üniversitesi, İşletme Fakültesi Beta Basım Yayım Dağıtım.

Kusluvan, S., Kusluvan, Z., Ilhan, I., and Buyruk, L. (2010). The human dimension a review of human resources management issues in the tourism and hospitality industry. Cornell Hospitality Quarterly, 51(2), 171-214.

Kuşluvan, Z., ve Kuşluvan, S. (2005). Otel işletmelerinde iş ve işletme ile ilgili faktörlerin işgören tatmini üzerindeki görece etkisi: Nevşehir örneği. Anatolia: Turizm Araştırmaları Dergisi, 16(2), 183-203.

Lu, L., Lu, A.C.C., Gursoy, D., and Neale, N.R. (2016). Work engagement, job satisfaction, and turnover intentions: A comparison between supervisors and line-level employees. International Journal of Contemporary Hospitality Management, 28(4), 737-761.

Macky, K., and Boxall, P. (2007). The relationship between 'high-performance work practices' and employee attitudes: an investigation of additive and interaction effects. The International Journal of Human Resource Management, 18(4), 537-567.

Meyer, J.P., and Allen, N.J. (1991). A three-component conceptualization of organizational commitment. Human Resource Management Review, 1(1), 61-89.

Mcguire, D. and Kissack, H.C. (2015) Coaching and Mentoring. R. F. Poell, S. Rocco, ve G. L.Roth içinde, The Routledge Companian to Human Resource Development, 521-530. Abington: UK: Routledge.

Murphy, K., Torres, E., Ingram, W. and Hutchinson, J. (2018) A review of high-performance work practices (HPWPs) literature and recommendations for future research in the hospitality industry, International Journal of Contemporary Hospitality Management, 30(1), 365-388.

Nankervis, A.R., and Debrah, Y. (1995). Human resource management in hotels: a comparative study. Tourism Management, 16(7), 507-513.

Ozturk, A.B., Hancer, M. and Im, J.Y. (2014). Job Characteristics, Job Satisfaction, and Organizational Commitment for Hotel Workers in Turkey, Journal of Hospitality Marketing $\mathcal{E}$ Management, 23:3, 294-313.

Paillé, P., Bourdeau, L., and Galois, I. (2010). Support, trust, satisfaction, intent to leave and citizenship at organizational level: A social exchange approach. International Journal of Organizational Analysis, 18(1), 41-58.

Park, S., Yang, B., and Mclean, G.N. (2008). An Examination of Relationships between Managerial Coaching and Employee Development. Academy of Human Resource Development Conference in the Americas, Panama City, FL, Şubat 20-24.

Raub, S., and Robert, C. (2013). Empowerment, Organizational Commitment, and Voice Behavior in the Hospitality Industry Evidence from a Multinational Sample. Cornell Hospitality Quarterly 54(2), 136-148.

Robinson, S.L. and Rousseau, D.M. (1994). Violating the psychological contract: Not the exception but the norm. Journal of Organizational Behavior, 15, 245-259.

Sadullah, Ö. (2015). İnsan Kaynakları Yönetimi, İ.Ü. İşletme Fakültesi, Beta Basım Yayım Dağıtım A.Ş.

Safavi, H.P., and Karatepe, O.M. (2018). High-performance work practices and hotel employee outcomes: The mediating role of career adaptability. International Journal of Contemporary Hospitality Management, 30(2), 1112-1133. 
Schoorman, F. D., Mayer, R.C., and Davis, J. H. (2007). An integrative model of organizational trust: Past, present, and future. Academy of Management Review, 32(2), 344-354.

Searle, R. H. and Dietz, G. (2012). Trust and HRM: Current insights and future directions. Human Resource Management Journal, 22, 333-342.

Sürücü, Ö., Öztürk, Y., Okumus, F. and Bilgihan, A. (2019). Brand awareness, image, physical quality and employee behavior as building blocks of customer-based brand equity: Consequences in the hotel context. Journal of Hospitality and Tourism Management, 40, 114-124.

Şahin, F. (2011). Lider-üye etkileşimi ile işten ayrılma niyeti arasındaki ilişki üzerinde cinsiyetin etkisi. Ege Akademik Bakış, 11(2), 277-288.

Tan, H.H. and Lim, A.K.H. (2009). Trust in co-workers and trust in organizations. The Journal of Psychology, 143(1), 45-66.

Tekleab, A., and Taylor, M. (2003). Aren't there two parties in an employment relationship? Antecedents and consequences of organization-employee agreement on contract obligations and violations. Journal of Organizational Behavior, 24(5), 585-608.

TUIKK. (2021, Ocak 15). Türkiye İstatistik Kurumu Haber Bülteni: ttps://data.tuik.gov.tr/ adresinden alındı.

Walton, R.E. (1985). From control to commitment in the workplace. Harvard Business Review, 63, 77-85.

Wasti, S.A. (2000). Örgütsel bağllllğı belirleyen evrensel ve kültürel etmenler: Türk kültürüne bir bakış, Der. Z. Aycan, Türkiye'de Yönetim, Liderlik ve İnsan Kaynakları Uygulamaları, Ankara: Türk Psikologlar Derneği Yayınları, 201-224.

Whitener, E.M. (2001). Do 'high commitment' human resource practices affect employee commitment? A cross level analysis using hierarchical linear modeling. Journal of Management, 27: $515-536$.

Yorgun, S., Keser, A. and Yilmaz, G. (2009) The relationships of job and life satisfaction with intention to leave among unionized hotel employees in Turkey. İşgüç Endüstri İlişkileri ve İnsan Kaynakları Dergisi, 11(2): 55-67.

Zeytinoglu, I.U., Keser, A., Yilmaz, G., Inelmen, K., Ozsoy, A. and Uygur, D. (2012). Security in the sea of insecurity: Job security and intention to stay among service sector employees in Turkey. The International Journal of Human Resource Management, 23(13), 2809-2823. 